\title{
RESTRICTING HOME VISITS: TOWARD MAKING THE LIFE OF THE PUBLIC ASSISTANCE RECIPIENT LESS PUBLIC
}

\author{
Douglas Q. WIGKHaM $\dagger$
}

Most of the recent constitutional litigation challenging offensive practices in the administration of public assistance programs has been based on notions of due process and equal protection of the laws. Courts have struck down the substitute father rule ${ }^{1}$ and local residency requirements. ${ }^{2}$ Within the last year, litigants have succeeded in establishing a constitutional right to a fair hearing prior to termination of welfare payments ${ }^{3}$ and have unsuccessfully asserted the illegality of maximum limits on amounts to be given to family units regardless of size. ${ }^{4}$ All of these cases represent attempts to purge the administration of public assistance programs of practices generally regarded as abuses of the welfare system because they deny benefits to otherwise eligible persons for unconstitutional reasons. ${ }^{5}$

This fall, the United States Supreme Court will hear arguments in another such case, James $v$. Goldberg. ${ }^{*}$ The controversy arose when Mrs. James, a recipient of Aid to Families with Dependent Children (AFDC), refused to permit a New York City Social Service Depart-

$\dagger$ A.B. 1963, LL.B. 1966, Yale University. Member, Illinois Bar.

The author wishes to acknowledge the encouragement of Barbara Ann Pope and David P. Beverley of the University of South Carolina Graduate School of Social Work faculty.

1 King v. Smith, 392 U.S. 309 (1968). The Alabama regulation involved in this case provided that any male who "cohabitated" with the mother of a family otherwise eligible for AFDC payments be considered a "substitute father," thus disqualifying the family, because 42 U.S.C. $\$ 606$ (a) (1964) requires that one parent be continually absent from the family. In invalidating the regulation, the Supreme Court did not reach the equal protection argument advanced by the plaintiffs because it found that for Alabama's definition of "parent" to include a substitute father with no legal support duty was inconsistent with Congress' use of the word in $\$ 406$ (a) of the Social Security Act. 392 U.S. at 329-34.

2 Shapiro v. Thompson, 394 U.S. 618 (1969) (equal protection).

3 Goldberg v. Kelly, 397 U.S. 254 (1970) (due process) ; Wheeler v. Montgomery, 397 U.S. 280 (1970) (due process).

4 Dandridge v. Williams, 397 U.S. 471 (1970) (holding maximum limits on family grants not a violation of the equal protection clause).

5 See, e.g., Harvith, The Constitutionality of Residence Tests for General and Categorical Assistance Programs, 54 CALIF. L. Rev. 567 (1966); Reich, Individnal Rights and Social Welfare: The Emerging Legal Issues, 74 YALE L.J. 1245 (1965); Wickham, Public Welfare Administration: Quest for a.Workable Solution, 58 GEo. L.J. 46 (1969).

6303 F. Supp. 935 (S.D.N.Y. 1969), prob. juris. noted sub nom. Wyman v. James, 397 U.S. 904 (1970). 
ment caseworker ${ }^{7}$ to enter her home for a scheduled, daytime "home visit." \$ The caseworker sought to comply with New York State regulations ${ }^{9}$ requiring caseworkers periodically to interview public assistance recipients in their homes. Following Mrs. James' refusal to grant entry and a prior hearing on the issue of termination, the Department discontinued her AFDC payments. She then brought a class action to enjoin the Department from terminating welfare payments on the ground that termination for failure to allow a warrantless home visit violated her right to privacy and her fourth amendment right to be free from unreasonable searches. Without reaching the privacy issue, the three-judge federal court held two to one that New York could not constitutionally condition public assistance payments on the recipient's willingness to relinquish her fourth amendment right. ${ }^{10}$ An injunction forbidding the state from continuing this practice issued, and Mrs. James was reinstated as an AFDC recipient.

Because the district court did not decide whether the home visit violated Mrs. James' right to privacy, the holding in James v. Goldberg

7 The term "caseworker" is used herein to denote any agent of a public assistance organization who is responsible for direct contact with and supervision of individual welfare recipients. Many of the people encompassed by this broad definition of "caseworker" are not, however, formally trained as social workers. The Department of Health, Education, and Welfare estimates that an effective public assistance program would require that $1 / 3$ of the social workers complete graduate training, but in 1964 only $4.8 \%$ had achieved this level of training. See DEPARTMENT OF HEW, TASK Force on Soctal Wort Education and Manpower, Closing the Gap . . . IN SOCIAL WORK MANPOWER 22-24 (1965). In addition, casework is only one of several recognized methods of social work including group work and community organization, and is losing popularity because of its inadequacies. See Briar, The Casezvork Predicament, 13 Socral WoRk, Jan. 1968, at 5. Consequently, all public assistance workers may not be caseworkers as that term is ordinarily used.

The term "caseworker" is nevertheless used broadly herein on the assumption that: (1) Public welfare agencies employ their line personnel as if they were all formally trained caseworkers whatever their actual training. Some agencies attempt to compensate for the lack of graduate-level schooling by providing in-service training. Regardless of the quality of his preparation, each worker is responsible for helping his "clients" overcome their social problems. (2) Whatever the method of social work utilized in a particular program, the welfare agency will always be inquisitive and the privacy of the recipient will fare no better until the basic reforms suggested herein are implemented.

8 This practice is not comparable to the "midnight search" held unconstitutional in Parrish v. Civil Service Comm'n, 66 Cal. 2d 260, 425 P.2d 223, 57 Cal. Rptr. 623 (1967). In that case the searches, labelled "Operation Bedcheck," occurred during the early morning hours, and the recipient subjected to the visit received no advance warning. Id. at 26, 425 P.2d at 225, 57 Cal. Rptr. at 62. See also Reich, Midnight Welfare Searches and the Social Secucrity Act, 72 Yale L.J. 1347 (1963). Mirs. James' caseworker, on the other hand, had notified her by mail one week in advance of the proposed visit to be scheduled at her convenience during business hours. 303 F. Supp. at 938 .

Although Mrs. James refused to meet with the caseworker in her home, she volunteered to "supply any information reasonable and relevant to her continued receipt of public assistance . . . . at the offices of the Department." Id.

9 N.Y. Soc. Services LAW §134 (McKinney 1966); 18 N.Y.C.R.R. \$ $\$ 351.10$, 351.21 (1962).

10303 F. Supp. at 945. 
does not depart from the mainstream of recent welfare litigation. The fourth amendment issue on which the decision turned had not been raised in earlier cases, but the result merely places one more procedural restriction on the administration of federally supported public assistance programs. ${ }^{11}$ A recipient may now insist, without risking termination of public assistance, that a caseworker obtain a search warrant from a magistrate before entering her home.

Mrs. James' right to privacy argument appears to be directed at violations of her right occurring after the caseworker entered her home. ${ }^{12}$ She alleged that "questions concerning personal relationships, beliefs and behavior are raised and pressed which are unnecessary for a determination of continuing eligibility." ${ }^{13}$ Forcing caseworkers to procure search warrants prior to conducting home visits fails to meet this objection, however, if the caseworker's discretion alone governs the conduct of the visit after he enters the home. ${ }^{14}$ Only a right of privacy firmly rooted in the law can afford the desired protection.

This direct confrontation between the recipient's right to privacy and mandatory home visits, a practice long considered essential to the effective administration of public assistance programs, ${ }^{15}$ may impart a new direction to welfare litigation. By threatening to make unavailable the requisite personal information, it directly challenges the system's attempt to govern the behavior and morality of recipients through restrictive eligibility requirements.

This Article will explore the recipient's interest in maintaining a zone of privacy, examine the legal protection currently afforded this privacy, and suggest ways in which the administration of public assistance programs can and should be reoriented to respect fully the privacy of the recipient.

11 The Social Security Act, 42 U.S.C. §301 (1964), as amended, (Supp. IV, 1969), presently authorizes federal support for four categorical state public assistance programs: (1) Old Age Assistance (OAA), id. $\$ \S 301-06$; (2) Aid to Families with Dependent Children (AFDC), id. $\$ \S 601-09$; (3) Aid to the Blind, id. \$\$1201-06; and (4) Aid to the Permanently and Totally Disabled (APTD), id. $\$ \$ 1351-55$. Attention has been focused primarily on invasions of privacy in the AFDC program, but because eligibility questions necessitating home visits to obtain information often arise in each of the other programs, James is also relevant to them.

12 Supplemental Memorandum in Support of Plaintiffs' Motion for Preliminary and Permanent Injunction at 13-18, James v. Goldberg, 303 F. Supp. 935 (S.D.N.Y. 1969) (relying on Griswold v. Connecticut, 381 U.S. 479 (1965)).

13 Complaint at 6, James v. Goldberg, 303 F. Supp. 935 (S.D.N.Y. 1969).

14 See K. Davis, Discrettonary Justice 180-88 (1969). The caseworker's discretion arises from his initial power over the public assistance recipient's income. Control of this discretion, whether by a new legal principle or administrative changes (or both), must be the central object of any serious attempt to reform public assistance administration.

15 See, e.g., Note, Rehabilitation, Investigation and the Welfare Home Visit, 79 YaLe L.J. 746 (1970). 


\section{Privacy and Invasions of Privacy}

In recent years many commentators have expressed concern over the diminishing scope of personal privacy in the United States. The demise of privacy is often attributed to the "information explosion" and to the increased utilization of computers capable of assimilating vast quantities of personal information. ${ }^{10}$ Fewer voices, however, have been raised on behalf of the privacy of the public assistance recipient, although invasions of his privacy predate the computer age..$^{17}$

Many conceive of privacy in terms of particular intrusions from which the individual has a right to be free. ${ }^{18}$ But a more positive and inclusive statement of the essence of privacy and its importance to every individual is needed to avoid undervaluing the recipient's privacy when weighing it against the administrative needs of public assistance programs.

Professor Charles Fried has demonstrated that privacy is more than a simple right to be left alone. ${ }^{19}$

As a first approximation, privacy seems to be related to secrecy, to limiting the knowledge of others about oneself. This notion must be refined. It is not true, for instance, that the less that is known about us the more privacy we have. Privacy is not simply an absence of information about us in the minds of others; rather it is the control we have over information about ourselves. ${ }^{20}$

16 Proposals for a completely computerized and centralized individual data bank have been offered. The reader might contemplate how complete a picture of himself could be constructed simply by combining his scholastic, military, taxation, credit, and employment records (to name only the most readily available sources of information). Retention of privacy should be a universal concern. See Karst, "The Files": Legal Controls over the Accuracy and Accessibility of Stored Personal Data, 31 Law \& Contearp. ProB. 342 (1966); Miller, Personal Privacy in the Computer Age: The Challenge of New Technology in an Information-Oriented Society, 67 Mich. L. Rev. 1091, 1128-56 (1969).

17 See Handler \& Rosenheim, Privacy in Welfare: Public Assistance and Juvetile Justice, 31 LAw \& CoNTEMP. ProB. 377 (1966); Reich, supra note 5.

18 The origin of the concept of a legal right to privacy is considered to lie in Warren \& Brandeis, The Right to Privacy, 4 HARv. L. REv. 193 (1890). A more recent exposition of this concept of the right and its legal foundation may be found in Griswold, The Right To Be Let Alone, 55 Nw. U.L. REv. 216 (1960).

19 Fried, Privacy, 77 Yare L.J. 475 (1968).

20 Id. 482. For similar analyses of the legal concept of privacy, see Beaney, The Right to Privacy and American Law, 31 LAw \& Contemp. PRoB. 253 (1966); Ruebhausen \& Brim, Privacy and Behavioral Research, 65 Couvm. L. Rev. 1184, $1188-90$ (1965). Professor Beaney defines the right to privacy as

the legally recognized freedom or power of an individual (group, association, class) to determine the extent to which another individual (group, class, asssociation, or government) may (a) obtain or make use of his ideas, writings, name, likeness, or other indicia of identity, or $(b)$ obtain or reveal information about him or those for whom he is personally responsible, or

$(c)$ intrude physically or in more subtle ways into his life space and his chosen activities.

Beaney, supro at 254. 
Privacy permits the individual to control the manner in which he relates to other human beings. Without the ability to preserve his privacy, an individual could not enter into the relationships of love, friendship, and trust so essential to our concept of human dignity. "To be deprived of this control not only over what we do but over who we are [in the eyes of others] is the ultimate assault on liberty, personality, and self-respect." 21

In the typical home visit by a welfare caseworker, the most obvious invasions of the recipient's privacy arise from the administration of the means test to determine initial and continuing eligibility. ${ }^{22}$ In applying this test, the welfare department reviews the recipient's financial status, thoroughly investigates her background for other resources from which she could derive support, and periodically rechecks her case to determine whether she is spending the grant properly and whether her need level has changed. In New York, for instance, the statute requires an investigator reviewing an application for assistance to seek information

as to the residence of such person, the name, age, religious faith, physical condition, earnings or other income, and ability to work of all members of the family, the cause of the person's condition, the ability and willingness of the family, relatives, friends and church to assist, and such other facts as may be useful in determining the treatment which will be helpful to such person. ${ }^{23}$

This constant surveillance and questioning forces the public assistance recipient to choose between retaining control over what is known about her most personal affairs or relinquishing that control to qualify for the economic assistance needed to provide her family with the essentials of life.

The AFDC program permits greater intrusions into the personal lives of recipients than the other assistance programs because each state determines whether AFDC children are being suitably housed and cared for. State and local authorities generally have discretion to define "suitability," ${ }^{24}$ and often condition the AFDC grant upon recipient compliance with an arbitrarily imposed standard of morality. ${ }^{25} \mathrm{HEW}$ 's

21 Fried, supra note 19 , at 485.

22 The perfidious effect of the means test is well-documented. E.g., Bendich, Privacy, Poverty, and the Constitution, 54 CALIF. L. Rev. 407 (1966); Handler, Controlling Official Behavior in Welfare Administration, 54 CALIF. L. REv. 479 (1966) ; Reich, supra note 8; Comment, Eligibility Determinations in Public Assistance: Selected Problems and Proposals for Reform in Pennsylvania, $115 \mathrm{U}$. PA. L. Rev. 1307 (1967).

23 N.Y. Soc. Services LAW § 132 (McKinney Supp. 1970).

24 W. Betr, Am to Dependent ChIIDRen 29 (1965) ...

25 See Handler \& Rosenheim, supra note 17; tenBroek, California's Dual System of Family Law: Its Origin, Development, and Present Status, 17 STAN. L. REv. 614 (1965). 
Flemming Ruling requiring the states to continue aid to the family unless the children are relocated from the unsuitable home may limit the impact of this discretionary power, ${ }^{2 B}$ but arbitrary intrusions into recipients' lives will persist until the vague eligibility requirements are altered.

Neither the complaint nor the opinion in James v. Goldberg spells out the kind of questioning to which the plaintiff objected, but one can safely surmise several of the likeliest lines of inquiry. Despite the Supreme Court's decision in King v. Smith, ${ }^{27}$ a man in the house remains a frequent source of concern to public assistance agencies vigilant in their search for alternative sources of support for the needy family. ${ }^{28}$ The demand for the names and addresses of all relatives also leads to invasions of privacy when the agency proceeds to track down the relatives and dun them for support. ${ }^{29}$ For any number of valid reasons, a young mother applying for AFDC benefits might wish to conceal her predicament from her parents and other relatives. Conversely, the relatives have a strong interest in avoiding the scrutiny of the welfare agency, particularly if their relationship with the applicant is attenuated and their incomes meager. Under present requirements, however, the recipient must sacrifice control over her relationship with her relatives and risk subjecting them to bothersome inquiries before she can qualify for aid.

The most recent public role forced on public assistance recipients is that of "research object." Research sometimes passes as justification for caseworker interrogation, but the questions concerning family status and marital partners are no less personal as a result. ${ }^{30}$ More important, the potential uses of the information obtained remain the same.

Less obvious are those invasions of privacy wrought under the social service amendments to the Social Security Act. The Act was amended first in $1956^{31}$ to encourage the states to offer social services

$26 \mathrm{HEW}$ issued this ruling after Louisiana removed a majority of the black public assistance recipients from its roles by declaring unsuitable any home in which a parent was responsible for an illegitimate child. See W. BELL, silpra note 24 , at 138-48.

27392 U.S. 309 (1968).

28 The most recent round of litigation on this subject concerns state regulations creating "presumptions of support" from a man assuming the role of a spouse (MARS) as defined by the regulation. E.g., Lewis v. Martin, 397 U.S. 552 (1970); Grubb v. Sterrett, 2 CCH Pov. L. REP. $\{11,533$ (N.D. Ind., May 7, 1970).

29 See Bell, Relatives' Responsibility: A Problem in Social Policy, 12 Soctal Work, Jan. 1967, at 32. Bell argues persuasively that this burden of support falls on those who can least afford it, id. 37, destroys family cohesion, id. 38-39, and conserves public funds primarily ·by deterring applicants from applying, $i d .39$.

${ }^{30}$ See Ruebhausen \& Brim, supra note 20, at 1203.

31 Act of Aug. 1, 1956, Pub. L. No. 880, §312, 70 Stat. 848 (1956), amending 42 U.S.C. $\$ \$ 601-03$ (1964). 
by providing federal aid, and then in $1962^{32}$ to require the states to integrate social services into their public assistance programs. The 1956 amendment to the AFDC portion of the Act evidenced a congressional intent to make acceptance of social services (prescribed by the caseworker) a condition for receiving the basic economic grant. ${ }^{33}$ But by conditioning the grant of economic subsistence on the acceptance of social services such as instruction on house keeping, raising children, budgeting the grant, or conducting one's social life, the administrators of public assistance deprive the recipient of control over her existence. Although these services may be offered with the best motives, the recipient cannot accept them voluntarily: by rejecting the offer she risks losing the grant. ${ }^{34}$

Admirable motives notwithstanding, treating the public assistance recipient in this way contradicts the basic goals of the AFDC program:

[T]o help maintain and strengthen family life and to help such parents or relatives to attain or retain capability for the maximum self-support and personal independence consistent with the maintenance of continuing parental care and protection .....$^{35}$

The invasions of privacy cited above tend to transform recipients into dependent citizens stripped of the critical ability to control the direction and style of their lives. ${ }^{36}$ The public assistance recipient is thus in a position analogous to Professor Fried's electronically monitored parolee: ${ }^{37}$ the recipient has failed to maintain independent economic status and must pay the price of continual supervision in exchange for a subsistence allowance. Relationships of trust are consequently foreclosed because " $[t]$ he negation of trust is constant surveillance . . . which minimizes the possibility of undetected default. The [recipient] is denied the sense of self-respect inherent in being trusted by the

32 Act of July 25, 1962, Pub. L. No. 87-543, \$104, 76 Stat. 185 (1962), amending 42 U.S.C. $\$ \S 601-05$ (1964).

33 The New York City Department of Social Services contends that an AFDC parent must accept services offered as a result of a home visit to remain eligible for assistance. Jurisdictional Statement of Appellant Wyman at 17-18, Wyman v. James, 397 U.S. 904 (1970) (noting probable jurisdiction). See also McEntire \& Haworth, The Two Functions of Public Welfare: Income Maintenance and Social Services, 12 SOCIAL WoRK, Jan. 1967, at 22, 28.

34 Supplemental Memorandum, supra note 12, at 21-23. See also Lynumn v. Illinois, 372 U.S. 528 (1963) (confession obtained by police threat to have welfare benefits terminated held coerced). As long as the caseworker wields discretionary power over the recipient's subsistence income, no rational recipient would refuse his requests.

3542 U.S.C. $\$ 601$ (1964).

36 "[W] deprive an individual of the one freedom that is primary to all others and that endows him with the core of his dignity: the freedom to make a shambles of his life." Miller, Vahue Dilemmas in Social Casezork, 13 SocIAL WORK, Jan. 1968 , at 27,30 .

37 Fried, supra note 19, at 475-76. 
government which [provides aid]." 38 Thus deprived, the AFDC mother cannot be expected to function as a full-fledged citizen. Nor can her children, for they will not experience the privacy essential to the development of mature human relationships.

To enjoy privacy, the public assistance recipient must control her relationship with the caseworker and the program. She alone must set the moral tone of her home, and departmental investigations of her case should not unnecessarily disrupt her relationships with her friends and family by broadcasting the facts of her economic plight.

Yet the recipient's privacy must be subjected to some restrictions in the administration of public assistance programs. The legitimate needs of the department and of recipient privacy require reconciliation to the satisfaction of both. The remainder of this Article will examine the legal basis for protecting the public assistance recipient's privacy and then suggest how administrative needs and recipient privacy can be reconciled under these guiding legal principles.

\section{Privacy and the Constitution}

Mrs. James presented two distinct legal theories in support of her attack on warrantless home visits: that the state may not constitutionally compel the recipient to relinquish fourth amendment rights as a condition to aid, ${ }^{39}$ and that the constitutional right to privacy itself limits the discretion of the caseworker once inside the home pursuant to a warrant. ${ }^{40}$ The court never reached the second claim, ${ }^{41}$ although this line of argument contains the potentially more effective legal guidelines for reconciling the administrative and recipient interests in public assistance.

\section{A. The Fourth Amendment as Protection}

In deciding that the state cannot condition public assistance benefits on the recipient's willingness to relinquish fourth amendment rights, the James court examined several questions. First, finding that the fourth and fourteenth amendments protect persons from unwarranted governmental intrusions whether or not the object of the intrusion is to uncover and seize evidence for use in a criminal prosecution, the court held that the home visit constitutes an unreasonable search. ${ }^{42}$ The

38 Id. 490-91.

39 The court accepted this argument. 303 F. Supp. at 945.

40 Supplemental Memorandum, supra note 12.

41 Although the court restricted its holding to the fourth amendment issue, it recognized that one important function of the fourth amendment is to protect the traditional sphere of privacy, the home, from unwarranted official intrusions. $303 \mathrm{~F}$. Supp. at $941,946$.

42 Id. at 944. 
court reasoned that "a search of a private dwelling without a warrant or proper consent is presumptively 'unreasonable," "43 and that the fourth amendment affords "basic protection for everyone," not just for those accused of committing crimes. ${ }^{44}$ Second, because the home visit involves a significant infringement of a fundamental right, the court held that the government must demonstrate a compelling interest to conduct warrantless visits. ${ }^{45}$ Third, although the defendant commissioner of the New York City Department of Social Services failed to produce evidence sufficient to justify creating a new exception to the search warrant requirement, the court did acknowledge the special circumstances embodied in the home visit by adopting a "relaxed standard" for determining probable cause for the issuance of search warrants to caseworkers. ${ }^{46}$

\section{The Home Visit as a Search}

The holding in James $v$. Goldberg follows logically from the purpose of the fourth amendment as articulated over the years by the Supreme Court, and particularly from Camara v. Municipal Court ${ }^{47}$ and See v. City of Seattle, ${ }^{48}$ cases in which the Court has applied the fourth amendment to administrative inspections. The general policy of the amendment is to protect the individual and his surroundings from unauthorized intrusions by government officials. ${ }^{49}$ In Schmerber v. Califormia, ${ }^{50}$ the Supreme Court held that a blood test administered in a hospital to a driver accused of drunken driving is a search under the fourth amendment and stated that: "The overriding function of the Fourth Amendment is to protect personal privacy and dignity against unwarranted intrusion by the State." ${ }^{51}$ Thus, the James court correctly assumed that " $[t]$ he Fourth Amendment . . . governs all intrusions by agents of the public upon personal privacy and security." 52

43 Id. at 940 .

44 Id. at 941.

$45 I d$.

46 [I]t must be noted that the Court in Camara v. Municipal Court . . emphasized that "a health official need [not] show the same kind of proof to a magistrate to obtain a warrant as one must who would search for the fruits or instrumentalities of crime." This would appear applicable to the instant proceedings.

Id. at 944 .

47387 U.S. 523 (1967).

48387 U.S. 541 (1967).

49 See LaFave, Administrative Searches and the Fourth Amendnent, 1967 SuP.

C. Rev. $1,20$.

50384 U.S. 757 (1966).

51 Id. at 767 (emphasis added).

$52303 \mathrm{~F}$. Supp. at 940 (emphasis added) (citing Terry v. Ohio, 392 U.S. 1, 18 (1968)). 
The James court relied heavily on Camara $v$. Municipal Court, ${ }^{53}$ in which the defendant refused to permit a municipal inspector to enter his house in San Francisco to conduct a routine inspection for violations of the local housing code. The inspector returned twice without a warrant before charges were brought under a local statute purportedly providing authority for warrantless inspections. The Court accepted the defendan's allegation that the section of the local housing code authorizing entry without a warrant and without probable cause violated the fourth amendment. The Court noted that the practical effect of forcing the defendant to risk criminal prosecution if he wished to challenge the inspector's decision to search his home "is to leave the occupant subject to the discretion of the official in the field. This is precisely the discretion to invade private property which we have consistently circumscribed by a requirement that a disinterested party warrant the need to search." 54 In Camara's companion case, See v. City of Seattle, the Court established the warrant requirement for administrative inspections of commercial property as well. ${ }^{55}$

The public assistance home visit can arguably be distinguished from the administrative inspection cases because the purposes of and the needs for the intrusions differ. The sole purpose of the inspector's visit in Camara was to seek out intentional or inadvertent violations of the local housing code. But a dual purpose lies behind the home visit. The practice of visiting recipients' homes initially arose out of the need to review eligibility. ${ }^{56}$ Because this purpose for the visit is to discover any changes in the recipient's eligibility status, ${ }^{57}$ the caseworker conducting the home visit is an investigator. With the addition of the service requirements to the federal program, the secondary function of the caseworker, the provision of social services, took on new importance. Thus the second fundamental purpose of the home visit is to establish a productive caseworker-client relationship through which the former can encourage the latter's "social rehabilitation." 58

53387 U.S. 523 (1967). The Jantes court also quoted extensively from District of Columbia v. Little, 178 F.2d 13 (D.C. Cir. 1949), aff'd on other grounds, 339 U.S. 1 (1950), in which Judge Prettyman argued forcefully for this broad interpretation of the term "search."

54387 U.S. at $532-33$.

65387 U.S. at 545.

56 See W. Bell, supra note 24 , at 3-13.

57 See N.Y. Soc. SERvices LAw \$134-a (McKinney Supp. 1969); 18 N.Y.C.R.R. $\S \S 351.10,351.21$ (1962).

58 In 1962, the Social Security Act was amended to require states to include social service programs in their annual AFDC proposals before approval could be granted. See 42 U.S.C. §602(a) (14) (Supp. IV, 1969). But such plans apparently have little effect on the recipients. The only major empirical study in this area concluded that "very little social service activity goes on.". Handler \& Hollingsworth, Stigma, Privacy, and Other Attitudes of Welfare Recipients, 22 STAN. L. REv. 
Although a certain amount of ambiguity attends this combination of functions, the home visit is usually more benevolent than a housing code inspection. As the lone dissenter in James argued, the purpose of the home visit "is to assist the children, not to catch the children's mother in a violation of the law." 59 To concentrate on the benevolent purpose of the home visit, however, would ignore the reality of the investigative function leading, as it does, to the periodic reexamination of eligibility.

The James court did not rely on such an analysis, but did take judicial notice of provisions of the New York Social Services Law effectively requiring caseworkers to report any evidence of welfare fraud coming to their attention. Under the statute, which defines welfare fraud to include fraudulent applications and failure to report income not included in the original or subsequent eligibility reviews, the caseworker "shall refer the facts and evidence available to him to the appropriate . . . prosecuting official." ${ }^{00}$ Assuming that caseworkers in other states operate under similar regimens, the investigative function pervades all home visits. ${ }^{61}$ If the caseworker came to the recipient's home to discuss medical care, for instance, and saw in the course of the visit luxury items of any sort, this information would likely be used to initiate further investigation leading finally to prosecution. This possibility, the court found, "sustained" its decision to classify home visits as searches. ${ }^{62}$

Yet the definition of "search" set forth in the court's holding encompasses a broader area than investigations leading to criminal prosecution. In conjunction with its conclusion that the fourth amendment protects not only those suspected of committing crimes but also the innocent from unwarranted governmental intrusions, the James court stated:

To attempt to draw a distinction regarding the applicability of the Amendment dependent upon whether the caseworker intends to counsel the recipient as to how best to utilize his limited resources or to look for evidence of fraud, would invite a trial of every official's purpose-a task which would undoubtedly pervert the intent of the Amendment. There exists no valid reason for varying the protection afforded by

1,10 (1969). The data may not adequately support this generalization, however, because the statistical sample was drawn from two medium-sized cities and severai rural counties in Wisconsin. Also, the authors point out that "the Wisconsin AFDC program is best characterized as one of minimal caseworker intervention and regulation." Id. 8. A program of this nature could not support active social services.

59303 F. Supp. at 946 (McLean, J., dissenting).

60 N.Y. Soc. Services LAw $\$ 145$ (McKinney Supp. 1969).

81 See Note, sipra note 15.

62303 F. Supp. at 944. 
the Amendment even assuming that the home visit is an effort to deal with a purely "social problem."

In support of this conclusion, the court cited Verdugo v. United States, ${ }^{64}$ a narcotics offense case in which the court held that illegally seized evidence, suppressed at trial, could not be considered during the sentencing process merely because sentencing is "an effort to deal with a 'social problem.' " 65 The Verdugo court looked to the Camara decision for support for this statement.

In Camara, however, as in Verdugo, evidence produced by the search would have been used in a criminal proceeding. ${ }^{68}$ In James, the court noted the potential for a criminal proceeding but did not rely on this possibility in labelling the visit a search. Thus, the breadth of the court's holding forbids entry even if, at some future date, the investigative function is eliminated or simply segregated from the rehabilitative function. This holding emphasizes that the essence of the evil prohibited by the fourth amendment is the unwarranted intrusion into the individual's home by any government official.

\section{Permissibility of Warrantless Home Visits}

If home visits are searches within the meaning of the fourth amendment, then to permit a caseworker to enter an AFDC recipient's home without her free consent ${ }^{67}$ and without a search warrant requires the creation of a new judicial exception to the general prohibition against warrantless searches. ${ }^{68}$ None of the present narrowly drawn exceptions to the search warrant requirement encompasses the normal home visit. ${ }^{69}$ Thus, unless a new exception is created, a public assist-

63 Id. at 942 .

64402 F.2d 599 (9th Cir. 1968).

65 Id. at $611 \mathrm{n} .20$.

68387 U.S. at 531 . The Court noted that, even if the violation did not lead to a criminal charge, failure to comply would.

67 Because the caseworker wields great discretionary power over the recipient subjected to the search, a court would be unlikely to find that her consent was ever freely given. See Reich, supra note 8, at 1349 . Therefore, this exception can be ignored for the purpose of this discussion.

68 In Frank v. Maryland, 359 U.S. 360 (1959), the Supreme Court in effect authorized such an exception when it upheld a state's conviction of a homeowner for refusing to permit health inspectors to enter his home in the course of a search for the source of a rat infestation. In Camara, the Court explicitly overruled Frank, finding no public interest sufficient to justify an exception to the warrant requirement for administrative searches. 387 U.S. at 528 .

69 In addition to the exception for searches to which valid consent is given, warrantless searches are permitted when incident to lawful arrests, Chimel v. California, 395 U.S. 752 (1969); when a risk exists that the evidence of a crime will be destroyed if the search is not conducted immediately, Schmerber v. California, 384 U.S. 757 (1966) (sanctioning immediate blood test for drunken driving suspect); and when the police are in "hot pursuit" of a suspected criminal, Warden v. Hayden, 387 U.S. 294 (1967). 
ance home visit, now classified as a search, would be unreasonable if conducted against the recipient's wishes without a warrant.

In considering the possibility that a new exception might be warranted, the James court held that

when the conditions annexed to the enjoyment of these benefits require a waiver of rights secured by the Constitution, the governmental entity seeking to impose those conditions must show a compelling state interest therefore. No showing merely of a rational relationship to some valid governmental policy will suffice. ${ }^{70}$

By imposing this due process test, the court made the state's task of justifying its practice almost impossible. ${ }^{71}$

The New York City Department of Social Services attempted to respond to Mrs. James' constitutional attack with familiar arguments for forcing public assistance recipients to waive their rights in order to remain eligible for benefits. Stressing the need to obtain reliable information for the periodic eligibility reviews to prevent fraud, the officials argued that all public assistance recipients must be subjected to in-the-home inspections to protect the taxpayers' dollars. ${ }^{72}$ The Department also argued that by seeking benefits under the AFDC program, Mrs. James necessarily incurred an obligation to answer relevant questions as a prerequisite to establishing her eligibility. ${ }^{73}$ This obligation stems from the purpose of AFDC - to assure proper parental care for needy children in their homes whenever possible. Because of the importance placed on home conditions, they are an essential element in every eligibility decision. For the Department to make an informed-assessment on this subject necessitates a first-hand personal visit to the recipient's home by the caseworker. Finally, the state officials averred that the home visit provides the only reliable conduit for disseminating social services.

The James court found these arguments inadequate, basing its finding principally on the existence of alternative means of obtaining

70303 F. Supp. at 942.

71 The court felt a compelling interest particularly necessary when the state did not attempt to achieve its end in the manner which least infringed upon the recipient's rights. Id. at 943 .

The majority opinion in James cited five cases in support of the compelling interest requirement. Id. at 942 . All of these cases involve first amendment issues either directly or indirectly through the fourteenth amendment limitation on state activity. Following Shapiro v. Thompson, 394 U.S. 618 (1969), in which the Court held the constitutionally based right to travel fundamental, the fourth amendment interests involved in James are arguably sufficiently fundamental to merit application of the compelling interest standard.

72 Jurisdictional Statement, supra note 33 , at 15 .

${ }^{73} I d$. 
the information legitimately required for the eligibility determination. ${ }^{74}$ Several other considerations also militate against a finding of a compelling interest in this situation. Shapiro $v$. Thompson ${ }^{75}$ firmly rejected the "protect the public fisc" argument as a basis for impeding the exercise of a "fundamental" constitutional right. Similarly, in Goldberg $v$. Kelly, ${ }^{76}$ the Supreme Court held that increased fiscal and administrative costs, including the cost of temporarily disbursing benefits to ineligible persons, did not justify denying a hearing prior to terminating benefits. ${ }^{77}$ Furthermore, the James court rightfully ignored the argument that the visits are necessary to provide social services. Many welfare recipients undoubtedly need social services, but to foster a new exception to the search warrant requirement for this reason alone is to assume that the agency always knows the needs of the recipient better than she does herself and that the recipient should be forced to accept the services whether or not she desires them. In light of the court's rejection of these arguments, the public assistance agency faces an impossible burden in attempting to show a compelling interest in mandatory warrantless home visits.

\section{Adequacy of the Protection}

Assuming that James $v$. Goldberg will be affirmed on appeal, the question remains whether the application of the fourth amendment to home visits provides adequate protection for the recipient's interest in maintaining the maximum possible personal privacy. The key to this inquiry lies in the standard imposed by the court in issuing search warrants.

In criminal cases search warrants issue only when probable cause exists that specified items will be found on certain premises. ${ }^{78}$ To meet this standard a public assistance caseworker would have to show to the judge's satisfaction that a particular recipient was probably receiving benefits illegally by concealing assets or income in the home, or that a given family needed a particular service based on observations outside

74 The court suggested that the same information could be obtained by examining leases, birth certificates, and school records, and by requiring the children to undergo periodic medical examinations at public clinics. $303 \mathrm{~F}$. Supp. at 943 . The court also noted a proposed change in the HEW regulations as supporting its conclusion. For a discussion of the new regulations and further alternatives, see text accompanying notes $134-48$ infra.

75394 U.S. 618,631 (1969).

76397 U.S. 254 (1970).

77 Id. at 265-66.

${ }^{78}$ See LaFave, Search and Seizure: "The Course of True Law . . . Has Not . . Run Smooth," 1966 U. ILL. L. F. 255, 259-77; Note, Testing the Factual Basis for a Search Warrant, 67 Colun. L. REv. 1529 (1967). Admittedly, the showing need not be as exacting as the proof required at a criminal trial, but probable cause must be particularized. 
the home. Admittedly, outside sources might provide this information in some cases, but in the majority of instances an objective showing sufficient to persuade a magistrate of the need for a search would be difficult to make without previously entering the home. ${ }^{79}$

Presented with a similar problem in the administrative inspection cases, the Supreme Court ${ }^{80}$ recognized that the traditional probable cause standard might unduly obstruct efforts to further the legitimate public interests in eliminating health and safety hazards through enforcement of housing and fire codes. Consequently, the Court proposed and adopted a "relaxed standard" of probable cause to evaluate these particular applications for search warrants. ${ }^{81}$ By adopting this "relaxed standard," 82 the majority in James reopened any doors that the traditional search warrant requirement might have closed to caseworkers.

The Camara opinion offers little guidance for determining what specific showing would satisfy this new standard of probable cause. After "determining reasonableness [of the search] by balancing the need to search against the invasion which the search entails," ${ }^{83}$ the Court found the appropriate standard of probable cause in the legislative standards calling for the areawide housing code inspection.

Such standards, which will vary with the municipal program being enforced, may be based upon the passage of time, the nature of the building (e.g., a multi-family apartment house), or the condition of the entire area, but they will not necessarily depend upon specific knowledge of the condition of the particular dwelling. ${ }^{84}$

The essence of the Camara standard of probable cause calls for a willingness on the part of the magistrate to accept more general evidence as the basis for a warrant and to give weight to administrative decisions

79 A welfare department might permissibly rely on tips from informers to make a showing of probable cause. See Spinelli v. United States, 393 U.S. 410 (1969); Aguilar v. Texas, 378 U.S. 108 (1964). The "two-pronged" test for probable cause set out in Aguilar requires: (1) demonstration of circumstances sufficient to enable a magistrate to make an independent judgment of the validity of the informer's conclusion; and (2) support for the credibility of the informant. Id. at 114 . The best evidence for demonstrating probable cause would still likely be found in the recipient's home, but after James, the caseworker will have to obtain his warrant without the benefit of that information.

80 Camara v. Municipal Court, 387 U.S. 523 (1967); See v. City of Seattle, 387 U.S. 541 (1967).

81387 U.S. at 538.

82303 F. Supp. at 944 ; see note 46 supra.

83387 U.S. at $536-37$.

$84 I d$. at 538. 
to make certain searches on policy grounds. ${ }^{85}$ Applied to the public assistance situation, this standard permits a caseworker to show probable cause by producing general evidence of a need to establish or reestablish eligibility, or evidence that recipients probably need the services ordinarily provided as a part of the home visit. The magistrate must give weight to administrative findings that recipients similarly situated to the reluctant recipient frequently need caseworker services. For example, a warrant might be obtained by demonstrating that enough time had elapsed so that the recipient's financial circumstances had probably changed and therefore the grant must be recomputed. Evidence that a particular recipient has a history of instability and requires monthly caseworker visits, but never seeks out his caseworker, might justify a warrant in connection with the provision of social services. In an area highly concentrated with public assistance recipients, the burden might be met by an administrative decision that all persons need caseworker attention to prevent massive disturbances in the area.

Under this relaxed standard of probable cause, public assistance agencies will be able to accommodate the requirement imposed on them by James $v$. Goldberg with only minimal adjustment of their procedures. One may safely predict that caseworkers seeking search warrants will generally be successful whenever a recipient proves reluctant to grant the caseworker an appointment to visit the home. Once the caseworker obtains the warrant, he enters the recipient's home with the same uncontrolled discretion to invade her privacy. Because of the breadth of the new criteria for issuing warrants under the relaxed standard of probable cause and the vagueness of the present eligibility standards, no matter how carefully the magistrate draws the warrant, he will be unable to prevent the caseworker from extending the scope of the search after entering the house. And in the majority of cases, in which criminal prosecutions do not result, the exclusionary rule will not operate to enforce the restrictions in the warrant. Thus the fourth amendment search warrant provision should not be expected to protect adequately the privacy of the public assistance recipient.

\section{B. The Right of Privacy as Protection}

Nowhere does the Bill of Rights specifically mention privacy; nor does any direct judicial precedent authorize constitutional protection for the right Mrs. James claimed should be hers. Yet in Griswold $v$. Connecticut, ${ }^{86}$ the Supreme Court recognized, in hazy terms, a consti-

85 See LaFave, supra note 49, at 23-25.

86381 U.S. 479 (1965). 
tutional right of privacy which can and should be applied to protect the public assistance recipient's privacy.

In Griswold, the Court held that a Connecticut statute making criminal the use of or the assistance in the use of birth control apparatus violated the petitioners' right of privacy grounded in the "penumbras" of the various amendments contained in the Bill of Rights. To reach this issue the Court granted the petitioners-operators of a Planned Parenthood birth control clinic in New Haven-standing to assert the rights of the husband and wife actually employing the birth control device. Although at least three theoretical bases for the right of privacy can be discerned in the Griswold opinions, ${ }^{87}$ six of the Justices unequivocally recognized a right of privacy of constitutional dimension. Whether that right exists in the penumbras of the various amendments, ${ }^{88}$ among the "rights . . . retained by the people" under the ninth amendment, ${ }^{80}$ or among the fundamental aspects of liberty protected by the due process clause of the fourteenth amendment, ${ }^{90}$ the decision to strike down the Connecticut statute clearly rests on the petitioners' right to marital privacy. An attempt to expand the scope of Mrs. James' privacy vis-à-vis the public assistance agency might simply refer to Griswold and assert that the case stands for the proposition that the government may not deprive individuals of control over certain aspects of their lives. A look at recent judicial applications of the Griswold principles in five different factual situations will add flesh to the bareboned assertion that Mrs. James' privacy merits this constitutional protection.

Reliance on the Griswold principles has been most prevalent in a series of state and lower federal court decisions dealing with suspensions of public school students for violations of hair length regulations set by school officials. In each of these cases personal privacy claims have been raised; the results have been mixed.

In Breen v. Kahl, ${ }^{91}$ the Seventh Circuit ruled in favor of a high school student, expelled for failing to comply with the school hair length standard, when the administration failed to present objective proof of disruptions in the school's functions caused by the student's

87 See Dixon, The Griswold Penumbra: Constitutional Charter for an Expanded Law of Privacy?, 64 MICH. L. Rev. 197 (1965); Kauper, Pennmbras, Peripheries, Emanations, Things Fundamental and Things Forgotten: The Griswold Case, 64 MICH. I. Rev. 235 (1965); McKay, The Right of Privacy: Emanations and Intimations, 64 MICH. L. REv. 259 (1965). Some of the Justices carefully labelled this a right of marital privacy. E.g., 381 U.S. at 486 (Goldberg, J., concurring).

88381 U.S. at 484-85 (Douglas, J.).

89 Id. at 491-93 (Goldberg, J., concurring).

${ }^{00} \mathrm{Id}$. at 500 (Harlan, J., concurring); id. at 502 (White, J., concurring).

91419 F.2d 1034 (7th Cir. 1969), cert. denied, 398 U.S. 937 (1970). 
appearance. ${ }^{92}$ The court affirmed the existence of a constitutional right to wear one's hair according to one's personal tastes, and noted that this right could be grounded in Justice Douglas' penumbras or among. Justice Goldberg's unenumerated ninth amendment rights. ${ }^{93}$ In Ferrell v. Dallas Independent School District, ${ }^{9 \pm}$ however, the Fifth Circuit upheld the suspension of two students when the only proof of possible disruption offered by the school authorities consisted of their opinions that long hairstyles would lead to disturbances. ${ }^{95}$ The court agreed that hairstyle is a form of expression protected by the first amendment but held that the school district had shown a compelling interest in regulating the students. ${ }^{96}$

The majority view in this series of decisions seems to be that personal grooming is either a fundamental mode of self-expression protected by the first amendment or a matter of personal privacy shielded by the Griswold result. In either case, the school district must meet a substantial burden to justify its regulations. The minority view does not consider personal grooming fundamental and places a lesser burden of justification on the school officials. ${ }^{97}$

Although the holding in Stanley $v$. Georgia ${ }^{98}$ is not based on Griswold, the Supreme Court reemphasized in its Stanley opinion the primacy of the principles enunciated in Griswold. ${ }^{99}$ State officials entered Stanley's home on the authority of a search warrant issued in connection with an investigation of his alleged bookmaking activities. In the course of the search, the officials stumbled on three reels of film which they confiscated as obscene material. In reversing Stanley's conviction for possessing obscene movies, the Court ignored the failure of the state court to suppress the illegally seized film and relied instead

02 Accord, Reichenberg v. Nelson, 310 F. Supp. 248 (D. Neb. 1970) (college dress code); Sims v. Colfax Community School Dist., 307 F. Supp. 485 (S.D. Iowa 1970) (female student); Richards v. Thurston, $304 \mathrm{~F}$. Supp. 449 (D. Mass. 1969); Griffin y Tatum, 300 F. Supp. 60 (M.D. Ala. 1969); Yoo v. Moynihan, 28 Conn. Sup. 375, 262 A.2d 814 (Hartford County Ct. 1969).

93419 F.2d at 1036.

21392 F.2d 697 (5th Cir.), cert. denied, 393 U.S. 856 (1968). Justice Douglas dissented from the denial of certiorari, stating that: "It comes as a surprise that in a country where the States are restrained by an Equal Protection Clause, a person can be denied education in a public school because of the length of his hair." 393 U.S. at 856 .

95 Accord, Crews v. Cloncs, 303 F. Supp. 1370 (S.D. Ind. 1969) (grooming not a fundamental right analogous to marital privacy); Davis v. Firment, 269 F. Supp. 524 (E.D. La. 1967), aff'd per curiam, 408 F.2d 1085 '(5th Cir. 1969).

96392 F.2d at 703.

97 See, e.g., Leonard v. School Comm., 349 Mass. 704, 212 N.E.2d 468 (1965); Comment, Public Schools, Long Hair, and the Constitution, 55 IowA I. REv. 707, 708 (1970).

98394 U.S. 557 (1969).

$99 \mathrm{Id}$. at 564 . 
on the first amendment supplemented by Griswold's right of privacy to hold that the state may not regulate what an individual chooses to view or read in the privacy of his home. The Court found the state interest in protecting Stanley from self-corruption inferior to his fundamental first amendment "right to satisfy his intellectual and emotional needs in the privacy of his own home." 100 Comparing the state's argument to an "assertion that the State has the right to control the moral content of a person's thoughts," 101 the Court invalidated the Georgia legislation. An Indiana federal district court subsequently reached a similar result, basing its decision directly on the authority of Griswold. ${ }^{102}$ The court stated that prosecution for possession of obscene material without the intent to sell or distribute violated the defendant's right to privacy.

In the wake of the Stanley decision, the right to possess and smoke marijuana in the privacy of one's home has been urged as a defense to criminal prosecutions under statutes making mere possession of the drug a crime. Three times this assertion of privacy has been rejected by the courts. ${ }^{103}$ In each case the court determined that no "right to smoke" exists and that, in the absence of first amendment considerations, the state's interest in controlling dangerous drugs outweighs any privacy interest presented.

In another controversial field, the Supreme Court of California ${ }^{104}$ and a federal district court sitting in Wisconsin ${ }^{105}$ have overturned convictions for violations of state abortion laws when the operation occurred before the fetus quickened. ${ }^{100}$ These decisions rest squarely on the proposition that an individual woman's decision whether to bear children is a fundamental aspect of that personal and marital privacy into which the state may not constitutionally intrude. Both courts cited Griswold as authority for recognizing privacy as a controlling interest in this field.

$100 \mathrm{Id}$. at 565.

101 Id.

102 Henley v. Wise, 303 F. Supp. 62 (N.D. Ind. 1969). The court asserted that "[w] hile only the right of marital privacy is covered by Cotner and Griswold, it is clear that this right stems from the greater right to individual privacy." Id. at 67 (emphasis in original). The court further found that the statute had a chilling effect on the plaintiff's first amendment freedom of inquiry.

103 United States v. Drotar, 416 F.2d 914 (5th Cir. 1969) ; Borras v. State, 229 So. 2d 244 (Fla. 1969); Commonwealth v. Leis, 355 Mass. 189, -, 243 N.E.2d 898, 903-04 (1969) (right of privacy explicitly rejected).

104 People v. Belous, - Cal. 2d -458 P.2d 194, 80 Cal. Rptr. 354 (1969) (en banc), cert. denied, 397 U.S. 915 (1970).

105 Babbitz v. McCann, 310 F. Supp. 293 (E.D. Wis. 1970).

106 Quickening occurs during the fourth month of pregnancy. See id. at 299. 
In Keefe v. Organization for a Better Austin, ${ }^{107}$ an Illinois appellate court upheld an injunction prohibiting peaceful picketing at a real estate dealer's home. The pickets sought to publicize certain of the realtor's undesirable business practices. ${ }^{108}$ Although peaceful picketing and distribution of leaflets is ordinarily considered within the ambit of the first amendment, the court decided that the dealer's interest in the privacy of his home and home life merited greater weight. The court noted a history of decisions prohibiting efforts to bring an individual's business life to his home in this peaceful yet disturbingly effective fashion. ${ }^{109}$ Of course, the court permitted the picketing and leafleting to continue at the dealer's place of business.

An analysis of the cases noted above provides a framework for judicial decisions accepting or rejecting assertions under Griswold of a right to privacy. Initially, the interest to be protected must be categorized as within or without the area of marriage, home, and family life generally accepted in a free society to constitute the realm of personal privacy. The more clearly a given interest falls within this realm, the more compelling must be the governmental interest justifying a particular intrusion or deprivation. In the end, a balance must be struck between these interests. ${ }^{110}$

This process is apparent in the cases decided subsequent to Griswold. The decision whether or not to bear a child is recognized to be personal and private in the fullest sense, the decision to wear one's hair long less so. The decision to view obscene material or to smoke marijuana within the confines of one's home may be classified as private, but the state's interest in controlling drugs outweighs the individual's interest in using them. Conversely, the right of an individual to retreat from his business life into the privacy of his home outweighs even the fundamental first amendment right to picket peacefully. As the balance shifts along this continuum, judicial opinions manifest in varying degrees unanimity and confidence or conflict and uncertainty.

107115 Ill. App. 2d 236, 253 N.E.2d 76 (1969).

108 The pickets were from a group seeking to prevent real estate dealers in the Austin area from engaging in the practice of "blockbusting." Keefe and others apparently used the threat of integration to panic white residents into moving out.

109 Although the court did not cite Griswold, its description of the dealer's interest in "privacy and repose" is very much in point. Most important is the weight given that interest in the face of a conflicting constitutional right, the freedom to speak. Picketing a home during a labor dispute has generally been considered a violation of privacy beyond the pale of permissible activity. See Kamin, Residential Picketing and the First Amendment, 61 Nw. U.L. REv. 177, 198-205 (1966).

110 See Beaney, supra note 20, at 262-65; Emerson, Nine Justices in Search of a Doctrine, 64 MICH. L. REv. 219 (1965). The difference in result between this approach and the one taken in James lies in the distinction between prohibiting the intrusion altogether and permitting it to continue under the ineffective supervision of an impartial magistrate. 
How does Mrs. James fit into this framework? Her purposes ${ }^{111}$ in going to court were to prevent continuing surveillance and questioning about her personal and social life and to regain control over the management of her home and over raising her children. These objectives clearly pertain to the realm of constitutionally protected personal privacy described only in part by the facts of Griswold. ${ }^{112}$ In the absence of a showing of a compelling state interest for continuing to deprive public assistance recipients of the ability to attain these objectives, the protection of the constitutional right of privacy should be extended to them.

In the last five years several courts presented with various assertions of a right of privacy have not shied away from extending Griszold into new situations when they felt justice would be served thereby. Although the constitutional right of privacy enunciated in Griswold remains a shadowy concept difficult to apply, it has not been limited to the unusual facts of that case. Whether as a distinct constitutional concept or as part of the reviving doctrine of substantive due process, ${ }^{113}$ the right of privacy appears to be taking firmer roots in our scheme of constitutional order. Recognizing this principle for public assistance recipients will provide a comprehensible legal guide for reorienting the administration of the programs to respect and preserve the privacy of the recipient.

\section{Administrative Changes to Protect Privacy}

In the absence of judicial enforcement of recipients' right of privacy, several fundamental changes can be made in the administration of public assistance programs to protect more adequately the recipients' interests. Essential to any serious reform is the separation of the mechanism by which economic grants are made from the mechanism by which the public assistance agency makes social services available to its clients. Only by ceasing to tie rehabilitative casework services to the money grant can they be offered on a truly voluntary basis. A second important step is to revise the standards for determining eligi-

111 Although Mrs. James probably did not herself suffer from all of the entmerated difficulties, public assistance recipients as a class have experienced all of these invasions of privacy. See text accompanying notes $22-34$ supra.

112 See note 102 supra.

113 In his Griswold dissent, Mr. Justice Black inveighed against the revival of substantive due process because he felt the doctrine permitted judicial decisions based on the personal whims of a majority of the Justices. 381 U.S. at 511-18. Because susceptible to subjective definition, the right of privacy also raises the danger of inconsistent application. But privacy as conceived by Professor Fried can serve adequately as a guide to principled judicial decisions. Control by an individual over what is known about himself and over the moral tone of his own home are ideas generally understood and accepted in this society. The right of privacy is by no means as undefined as the term "liberty" in the due process clause. 
bility to focus solely on economic aid and to eliminate the morality or social behavior of the recipient from consideration. These revised criteria should be susceptible to objective verification to obviate the need for caseworker surveillance of recipients and their homes. Finally, the system for verifying information required to determine eligibility should be altered to minimize the necessity for invading the recipients' privacy. Legislators and administrators possess the power to effect these changes; they need not wait for a judicial declaration that the public assistance recipient has a right to privacy.

\section{A. Separating Economic Grants From Services}

Separating the distribution of the economic grant from the provision of services would be a major step toward ending the invasions of privacy now practiced in the name of social service and rehabilitation. ${ }^{114}$ When the recipient knows that as a practical matter she must submit to the services offered by her caseworker if she and her family are to eat and keep a roof over their heads, her consent is hardly voluntary. ${ }^{115}$ In effect, the recipient relinquishes control over her children and her home for the public assistance check she needs to insure the family's survival. Consequently, the caseworker gains inordinate control over traditionally private aspects of the family's life.

The practical experience of the social work profession reinforces the observation that the public assistance recipient should be encouraged to retain control over her personal affairs. The journals of the profession reveal a consensus that working with the client in his home is desirable and sometimes essential to success, ${ }^{116}$ but the profession also clearly considers the principle of "client self-determination"- that the client direct his own life with the help of the caseworker-paramount among its values. ${ }^{117}$

Client self-determination, a relatively new concept, has not always held this primary position, however. The "friendly visitor" and the staff member-forerunners of public assistance caseworkers-of the turn-of-the-century Charity Organization Society considered the ob-

114 See, e.g., Kahn, Social Services in Relation to Incone Security: Introductory Notes, 39 Social SERvice Rev. 381 (1965); McEntire \& Haworth, supra note 33, at 22.

115 See note 67 supra.

116 E.g., Levine, Treatment in the Home, 9 SocLAI WoRK, Jan. 1964, at 19; Shames, Use of Homemaker Service in Families That Neglect Their Children, 9 Socral Work, Jan. 1964, at 12; Wiltse, Social Casezvork Services in the Aid to Dependent Children Program, 28 Social Service Rev. 173 (1954).

117 See F. Biestek, The Casework Relationship 103 (1957); G. Hanteton, Theory \& Practice of Soctal Case Work 6, 43-46 (2d ed. 1951); H. Perliman, SCCIAL CASEWORK 64-83 (1957). 
jects of their charity seriously in need of moral uplift.118 With the development of the profession, caseworkers began to encourage their clients to participate in the search for solutions to the problems. Despite this increase in "client participation," the initiative and final authority remained in the caseworker. ${ }^{119}$ As psychological and psychiatric methods were introduced into social work technique, however, therapy became the keystone requiring that the client willingly accept treatment. ${ }^{120}$ Social workers recognized that their success depended on their ability to involve the client in the therapeutic process. The principle of client self-determination arose from this evolution, and the profession currently considers unethical any attempt by a caseworiker to force or trick the client into accepting treatment.

Observance of the ideal of client self-determination, however, suffers from the observable resistance of many poor clients to the caseworker's efforts to deal with their social problems. Thus new techniques straying from the principle of client self-determination have been introduced. For instance, caseworkers speak of aggressive casework or "reaching out" casework, each of which aims at involving reluctant clients. ${ }^{121}$ The caseworker initially attempts to "win the client over" to believing that he can be helped, that he can help himself, yet draws the line short of forcing the observably needy but reluctant client to accept the offers. Practitioners of this school of thought assume a less passive role in dealing with unwilling clients, but they universally recognize that the client must be at least neutral if not actually willing to cooperate before the social casework process can achieve any degree of success. ${ }^{122}$

In addition to allowing caseworkers to operate in a climate more nearly in accord with their theories, separating social services from the economic grant will improve the quality of caseworker services. ${ }^{123}$ Once the social work function is insulated from the investigative function, caseworkers making home visits will no longer be inhibited by

118 See Becker, Exit Lady Bountiful: The Volunteer and the Professional Social Worker, 38 Social SeRvice REv. 57 (1964).

119 See Keith-Lucas, $A$ Critique of the Principle of Client Self-determination, 8 SOCTAL WORK, July 1963, at 66.

120 Id. 67; see authorities cited note 117 supra.

121 See, e.g., Sunley, New Dimensions in Reaching-out Casezork, 13 SocIaL Work, Apr. 1968, at 64 .

122 The experience of the social work profession has led its members to conclude that forcing social services on reluctant recipients is self-defeating. $C f$. G. HAMILTON, supra note 117, at 169-79. Public assistance administrators would do well to heed their experience.

123 See Blum, Differential Use of Manpower in Public Welfare, 11 SocIaI Work, Jan. 1966, at 16. A more radical suggestion for accomplishing the same end is to make caseworker services available through private agencies. Recipients could then hire caseworkers to advocate their interests before the public agency. See Piliavin, Restructuring the Provision of Social Services, 13 SocIaL WORK, Jan. 1968, at 34. 
the statutory responsibility to report all evidence of noneligibility. ${ }^{124}$ Instead, they will be able to concentrate on providing the assistance and guidance they were originally intended to provide. Under such conditions, the principle of client self-determination can be implemented effectively, and the recipient will finally be free to choose whether or not to cooperate with the caseworker.

As caseworkers are freed to perform the task for which they are trained, the ability of public assistance agencies to recruit and retain trained personnel will also increase. ${ }^{125}$ The continual reinvestigation of all assistance cases occupies a major portion of the total available working time of the caseworker in the public assistance agency. But the school-trained social worker enters the profession equipped to form and make effective use of his relationship with the client in attacking the client's problems. Further, his social work training is a highly personal experience requiring him to delve extensively into his own personality so that he will be able to discern his clients' problems and distinguish them from his own. With this educational background, the social worker choosing to enter a public agency faces a Hobson's choice. He may accept a supervisory post or he may become a caseworker destined to spend most of his time performing clerical or investigative tasks. Because of this discouraging experience in the public agency, many caseworkers quit to work in private agencies or leave the social work field altogether. ${ }^{126}$

\section{B. Revising the Eligibility Criteria}

Many of the occasions for the invasions of privacy discussed above arise as a direct result of eligibility standards susceptible to moralistic interpretations. ${ }^{127}$ Consequently, critics of the present public assistance system sometimes despair of accomplishing any significant reform without entirely eliminating the means test. ${ }^{128}$ Proponents of negative income tax plans, for instance, concern themselves primarily with providing income supplements to meet economic need without requiring

124 See text accompanying notes 60-62 supra.

${ }^{125}$ Cf. Thompson \& Riley, Use of Professionals in Public Welfare, 11 SocraL WoRk, Jan. 1966, at 22.

126 Id. 23-24.

127 A glaring example is the transformation of the statutory requirement that one parent be absent before AFDC payments are made, 42 U.S.C. $\$ 606$ (a) (Supp. IV, 1969), into administrative requirements that the absent parent be interviewed by the department, see Comment, Eligibility Determinations in Public Assistance: Selected Problems and Proposals for Reform in Pennsylvania, 115 U. PA. L. REv. 1307 (1967), or that the absent father of an illegitimate child be named before any payments are made. Doe v. Harder, 310 F. Supp. 302 (D. Conn. 1970); Doe v. Shapiro, 302 F. Supp. 761 (D. Conn. 1969), appeal dismissed, 396 U.S. 488, rehearing denied, 397 U.S. 970 (1970).

128 E.g., Bendich, supra note 22 , at 425-34. 
investigation to determine whether the reasons for the need are acceptable. ${ }^{129}$ Of course, these proposals possess their own administrative difficulties involving the possibility of invasions of privacy similar to those presently occurring in public assistance. ${ }^{130}$

To reduce the potential for abuse, all eligibility criteria pertaining to the behavior of the recipient and not objectively verifiable should be eliminated. The criteria should be limited to the following economic considerations: (1) Income from employment, pensions, or other government programs must be less than a certain amount; and (2) the applicant must have less than a stipulated amount of other assets within her personal control from which support could be derived. Furthermore, once the department establishes that the applicant is eligible, it should then determine the amount of assistance the recipient receives solely from her financial situation. A standard of living can be established for a given area by observing the cost of food, clothing, shelter, and other necessities. After measuring the recipient's financial status against this standard, the proper amount of the grant remains a clerical judgment.

But a public assistance agency has a legitimate interest in preserving the fiscal integrity of its program by seeking to prevent fraud. How should it police the suggested economic criteria? Statements volunteered by the applicant at the time of application will serve adequately as a starting point for an initial eligibility determination. ${ }^{131}$ Whenever the information provided by the applicant at this stage appears invalid, verification may be accomplished in an objective manner without intruding upon the applicant's privacy. Information supplied by the applicant with reference to the number of children in the family and the amount of family expenses can be verified simply by having a clerk read birth certificates and receipts, if available, for such major items as rent, utilities, clothing, and food.

Ascertaining the applicant's exact income presents a more difficult problem. Yet a recipient's attempt to conceal substantial income from employment could probably be uncovered by examining social security records because employers are required by law to deduct social security payments from wages. The source of any regular pension income could likewise be verified by checking records available from other governmental sources. One source of income from employment not susceptible to easy verification would be cash received for casual labor. Assuming

${ }^{129}$ Tobin, Pechman, \& Mieszkowski, Is a Negative Income Tax Practical?, 77 YALE L.J. 1, 2 (1967).

130 See Popkin, Administration of a Negative Income Tax, 78 YALE L.J. 388, 393, 406-09 (1969); Comment, A Model Negative Income Tax Statute, 78 YALE L.J. $269,279,286$ (1968).

131 See text accompanying notes 13448 infra. 
that this work would be irregular, the cost of policing this source would probably exceed the amounts recovered or saved. If, however, a particular case gave rise to extraordinary suspicions of fraud, a warrant for a home inspection could be obtained, permitting an investigator to observe any signs of concealed assets in the home and to pursue purely financial questions.

Another potential source of support difficult for the caseworker to verify would be gifts from relatives or from men associating with the AFDC mother within or without the home. Any program attempting to establish the amounts received from these sources would be costly, time-consuming, and would obviously intrude upon the recipient's-and the donor's-privacy. Limiting the outside asset criterion to sources of support within the personal control of the applicant minimizes these costs and the intrusions resulting from attempts to verify the presence or absence of such assets. ${ }^{132}$ If the applicant wished to declare it, voluntary support from family or friends might be included in the recipient's income, but efforts by the public assistance agency to coerce relatives into supporting their kin should be eliminated. These relatives already pay taxes if they are able to contribute to the support of the applicant, and should be considered to have discharged their obligations. ${ }^{133}$

Whether the means test is revised or eliminated, the goal should be to rid subsistence level income maintenance programs of all dependency on the moral judgments of the administrators dispensing the funds. The fiscal integrity of the program can be maintained by inquiries directed exclusively to those financial transactions revealed by public records. In a society claiming to respect liberty and the dignity of the individual, the government should not trade income maintenance payments for control over the private lives of the recipients.

\section{Objective Verification: The New HEW Regulations}

Following the completion of successful tests of a new system for determining eligibility, ${ }^{134}$ the Department of Health, Education, and

132 Negative income tax proposals have also intentionally excluded, to varying degrees, these potential sources of support from the recipient's income because of the cost of enforcement and the effect on recipient privacy. See, e.g., Popkin, supra note 130, at 393-94 (relatives' gifts should be excluded) ; Comment, sipra note 130, at 279.

133 See Bell, supra note 29. Of course, to the extent that the man in the house or the relative bears a legal support duty, this statement would not apply. The resources would then be within the recipient's control.

134 See Hoshino, Simplification of the Means Test and Its Consequences, 41 Soctal SERVICE REv, 237, 241-45 (1967), reporting successful state-initiated tests in Alabama, California, Colorado, Maine, and West Virginia. Hoshino concludes on the basis of these tests that:

[T]here appears to be little question of the feasibility of simplifying the method of determining eligibility for assistance in the adult categories by 
Welfare recently promulgated a regulation requiring the states to implement an essentially declaratory system labelled the "simplified method." 135 The purposes of the new system as summarized in the text of the regulation include giving "full respect for the rights and dignity of applicants for, and recipients of assistance." 136 The regulations now require progressive implementation of the simplified method in all categories except AFDC during fiscal year 1970-71. Implementation of the new system in the AFDC program, originally scheduled for April 1, 1970, has been postponed indefinitely pending the results of further experimentation. ${ }^{137}$ Eventually, however, all eligibility determinations will be made according to the method described in the HEW regulation.

The regulation defines the simplified method as

an organized method by which the agency accepts the statements of the applicant for, or recipient of assistance, about facts that are within his knowledge and competence . . . as a basis for decisions regarding his eligibility and extent of entitlement. ${ }^{138}$

The public assistance agency can seek additional information whenever the statements volunteered by the applicant are "incomplete, unclear, or inconsistent, or where other circumstances . . . indicate to a prudent person that further inquiry should be made, and the individual cannot clarify the situation." 139 The method contemplates that quality control will be accomplished by fully investigating a significant sampling of the caseload. The remainder of the recipients will escape intensive investigation unless the sampling process reveals that more than three percent of the eligibility decisions are erroneous. If the three percent tolerance level established by the regulation is exceeded with regard to any eligibility factor, such as the number of children in the household, then the state will temporarily be compelled to verify all the decisions involving that factor. ${ }^{140}$ The regulation offers no guidance concerning the method for accomplishing this intensive verification, ${ }^{141}$ but the

using declarations and mailed questionnaires. The basic problems are the complexities of the eligibility policies themselves and the ingrained habits and attitudes of some staff members. . . . [T] There appear to be no serious contraindications to extending the simplified methods to all adult categories in all states.

Id. 245. The tests involved mostly Old Age Assistance recipients.

13545 C.F.R. $\S 205.20$ (1970).

$136 \mathrm{Id}$.

13735 Fed. Reg. 8366 (1970).

13845 C.F.R. $\$ 205.20$ (c) (1970).

130 Id. $\$ 205.20$ (a) (3) (emphasis added).

$140 I d$. $\$ 205.20$ (c) (5) (iii).

141 However, "[ $t]$ he system contemplates periodic review and monitoring of operations by the Department of Health, Education, and Welfare." Id. 
public assistance agency will presumably be free to resume its traditional methods of investigation when ordered to conduct full-scale verifications.

To the extent that the simplified method will limit the practice of exhaustive investigations of all applicants and recipients, its introduction will add to their privacy. Difficulties will continue to arise, however, for the occasional unfortunate recipient who finds herself the object of an intensive verification investigation. ${ }^{142}$ Only a pious statement of intent in the regulation limits the scope of the verifier's discretion. If the criteria for the eligibility decision were limited to economic data subject to objective verification, the kind of spot checking or corrective action contemplated by this regulation might permit the recipient to retain a measure of privacy. The present criteria, however, include the personal and moral issues used by public assistance agencies to justify the inquiries against which Mrs. James asserted her right of privacy. Simplifying the administration of the criteria by placing the program on a declaration basis will not greatly improve the situation unless the eligibility criteria are likewise revised.

An experiment underway in four New Jersey cities and one Pennsylvania city evidences the feasibility of the revised administrative system outlined in this section. ${ }^{143}$ The primary purpose of this experiment, funded by the Office of Economic Opportunity, is to measure the "work incentive" effect of varying levels of guaranteed income payments. The monthly payments guaranteed under the three-year program decrease if the recipient's earned income increases, but the scale assures the recipient that he will always benefit (receive more total income) by working. ${ }^{144}$ The method of administering the project, however, differs markedly from current methods of administering public assistance and closely resembles the administration of the federal income tax. Once a month the recipient family must report its income, enclosing all pay check stubs, and any change in family composition. ${ }^{145}$ Less frequently, an audit is conducted using a random sample comprising ten percent of the families. The information requested for the audit includes unemployment benefits, Social Security Account records, federal withholding tax forms (W-2), and a statement of cash expendi-

142 Because a number of erroneous determinations will result simply from bureaucratic confusion, one may anticipate a sizable number of $100 \%$ verifications, all at the expense of the taxpayer and the recipient's privacy.

143 See Can Handonts Make Better Wage Earners?, Business WeEk, Feb. 28, 1970 , at 80 .

144 Office of Economic Opportunity, Preliminary Results of the New Jersey Graduated Work Incentive Experiment 25, Feb. 18, 1970.

145 See Watts, Adjusted and Extended Preliminary Results from the Urban Graduated Work Incentive Experiment 6, June 10, 1970 (discussion paper, Institute for Research on Poverty, Univ. of Wis.). 
tures for the year patterned after the Internal Revenue Service annual personal expenditure form. ${ }^{146}$ Participants are encouraged to obtain the first three items of information by requesting duplicate forms from the respective federal administrative agencies.

The initial conclusions drawn from the experiment after one year of operation indicate that administrative costs will be at least fifty percent below the normal level among public assistance agencies, ${ }^{\mathbf{1 4 7}}$ and that eighty to ninety percent of the families can be expected to fill out and file correctly all the forms without extensive assistance from the project's staff. ${ }^{148}$ Furthermore, the experiment appears acceptable to the participants specifically because the concrete income analysis allows them to demonstrate need without the humiliation inherent in the present means test treatment. ${ }^{149}$ Because it treats recipients in much the same manner as the federal income tax system treats wealthier citizens, this project offers hope for an improved method of administering public assistance incorporating the suggestions embodied in this section of the Article.

\section{Concluston}

What is welfare? I asked my teacher. . . . her face got very hard. She looked at me the way I look at the cockroaches crawling over the old people on 104th Street. . . . Is welfare something you are born into, like the serfs were born into being serfs in the middle ages? Are you born into this world into what you are and stay as you are? . . .

I think welfare is bad. But I don't understand why it should be bad. Is welfare a punishment? Is Momma being punished for what she did when she was a girl almost as old as I am now? ${ }^{150}$

${ }^{146}$ Letter from Mrs. Jerilyn Fair, Admin. Assist., Council for Grants to Families to the author, Feb. 24, 1970, on file at the Biddle Law Library of the University of Pennsylvania.

147 The OEO report states that:

The estimated total cost per family for this type of administration is $\$ 72$ to $\$ 96$ per year, exclusive of work training and day care costs. This figure compares to the estimated cost of $\$ 200$ to $\$ 300$ per family per year for the existing welfare system, also excluding the costs of training and services. Preliminary Results, supra note 144, at 23.

148 BusINESS WEEK, supra note 143, at 82, attributes this finding to John $O$. Wilson, Assist. Dir., OEO. As a result of the success in New Jersey, new projects are being started in Iowa and North Carolina. Id.

149 See Shore, A Preliminary Report: Recipient Reaction to the Negative Income Tax Experiment 17-19, Aug. 30, 1970 (paper prepared for Mathematica, Inc., Princeton, N.J.).

150 J. Horwitz, The Diary of A.N.: The Story of the House on West 104TH STREET 14-15 (1970). A.N. is fictitious, but her pitiful existence on West 104th Street in New York City is a composite drawn from Mr. Horwitz's eight years of experience as a New York welfare caseworker. 
This is public assistance seen through the eyes of a girl whose mother is on AFDC. Few have the spirit to say, as she did:

I will run from this failure. I will outrun it for all the days of my life. It will never be faster than me. I will be swifter than it and always keep it at my back. It will never get ahead of me. I don't know what I will be running toward but I do know that I will be running from failure, and I will see West 104th Street as a life that is not worthy of existence. ${ }^{151}$

Contending for privacy for a family able to afford only a single room in which to live may seem odd. But without the privacy needed to develop mature human relationships, only the rare few will have the spirit to run fast enough to escape from the imprisoning ghetto into worlds of their own. 